\title{
PENTINGNYA MEMPELAJARI ADMINISTRASI DAN SUPERVISI PENDIDIKAN
}

\author{
Nofita Sari \\ E-mail \\ nofitasari91199@gmail.com \\ Universitas Negeri Padang
}

\begin{abstract}
ABSTRAK
Administrasi merupakan proses pengelolaan yang mengelola seluruh proses pendidikan, administrasi sanagat penting dalam dunia pendidikan karna dengan adanya administrasi maka proses pembelajaran dapat mengangkat pendidikan yang lebih baik, dan berjalan secara efektif dan efisien, pentingnya administrasi diantara: memberi pengetahuan, dapat melaksanakan tugas dengan baik, dan memberikan motivasi dan inovasi pada pendidik.
\end{abstract}

A. Pentingnya mempelajari administrasi dan supervisi pendidikan

Administrasi pendidikan merupakan kegiatan pengelolaan baik dengan tulis menulis maupun dengan alat tulis lainnya seperti komputer. Adminstrasi sangat diperlukan dalam dunia pendidikan, sebagaimana ketatausahaan di berbagai bidang pendidikan, adminstrasi memiliki peranan yang sangat penting dalam pendidikan. Karna dengan adanya administrasi dan supervisi pendidikan maka akan memudah kan proses pembelajaran dan memperlancarkan pendidikan secara efektif dan efisien.

Dengan adminstarsi dapat membantu kita dapat mengangkat pendidikan yang lebih baik, oleh karena itu kita sebagai mahasiswa atau pelajar seharusnya bisa memahami bagaimana proses administrasi pendidikan tersebut. agar pendidikan dapat maju dalam hal apupun karna guru sangat berperan penting dalam administrasi.

Lebih-lebih produk administrasi yang berupa dokumen seperti Ijazah, Sertifikat dan surat-surat penting lainnya akan mempunyai nilai tinggi sekali di mata hukum, jika akurasi isinya dijamin benar. Oleh karena itu data administrasi memerlukan kejujuran

Dalam bidang pendidikan, kebutuhan sangat diperlukan untuk mencapai pendidikan yang lebih baik, baik kebutuhan informasi mulai dari data lembaga, 
sarana kurikulum sampai dengan data asal dan kondisi ekonomi siswa, dan juga sangat diperlukan baik dari perorangan maupun lembaga-lembaga pemerintah dan swasta, maupun penelitian mahasiswa. Dalam memberikan pelayanan yang lebih baik bagi masyarakat, hal ini menjadi tantangan bagi pada pemikir administrasi pendidik dalam menciptakan format data administrasi pendidik dan sistem pengelolaan data administrasi kependidikan yang mengkoordinasi bergbagai keperluan.

Kita dapat mengetahui bahwa Administrasi itu adalah suatu lembaga pendidikan yang merupakan suatu sumber utama manajemen dalam mengatur proses belajar mengajar dengan tertib sehingga tercapainya suatu tujuan terpenting pada lembaga pendidikan tersebut. Kita dapat mengetahui bagaimana proses-proses berjalanya suatu administrasi pendidikan yang sebenarya harus dilakukan sebagai seorang pendidik. Karna dalam Administrasi Pendidikan itu tidak hanya membahas tentang catat-mencatat, keuangan, melainkan bagaimana kita dapat melaksanakan proses organisasi itu sesuai dengan apa yang telah kita rencanakan secara efektif dan efisien.

Dengan demikian kita dapat termotivasi untuk memberikan sesuatu yang berbeda yang dapat mengarahkan pada kebaikan menuju pada pendidikan yang lebih baik. dengan adanya administrasi dan supervisi pendidikan tersebut kita dapat memperbaiki setiap kesalahan yang kadang-kadang sering terjadi dalam mengelola adminstrasi pendidikan karna seorang guru akan menjadi pelaksana dan juga bertanggung jawab dalam administrasi agar pendidikan dapat berlangsung dengan baik dan lancar.

Menurut (Afriansyah, 2019) Pentingnya Mempelajari Administrasi dan Supervisi Pendidikan adalah :

1. Memberikan pengetahuan dan pemahaman

2. Agar dapat melaksanakan semua tugasnya dengan baik

3. Memberikan motivasi dan inovasi kepada guru dan calon guru

\section{B. Konsep profesi pendidik dan tenaga kependidikan}

Menurut sikun 1976 dalam (mariyana,n.d.) profesi itu pada hakikatnya adalah suatu pernyataan atau janji terbuka, bahwa seseorang akan mengabdikan dirinya kepada suatu jabatan atau pekerjaan dalam arti biasa, karena orang tersebut merasa terpanggil untuk menjabat pekerjaan tu. 
Jadi, dapat ketahui bahwa profesi pada hakikatnya merupakan suatu pernyataan atau janji dari seseorang yang mengabdi baik pada dirinya sendiri maupun pada jabatan yang ia kerjakan. Profesi memiliki peran yang sangat penting dalam pendidikan.

Suatu profesi mengandung makna penyerahan dan pengabdian penuh pada suatu pekerjaan yang mengimplikasikan tanggung jawab pada diri sendiri, masyarakat, dan profesi(supriadi, 1999). Menurut ciri-ciri pokok profesi: (1) pekerjaan itu memiliki fungsi dan signifikan sosial karena diperlukan untuk pengabdian kepada masyarakat. Jadi profesi tersebut sangat memerlukan pengakuan masyarakat. (2) menuntut keterampilan tertentu yang diperolah lewat pendidikandan latihan yang lama dan intensif serta dilakukan dalam lembaga tertentu yang secara sosial dapat dipertanggung jawab. (3) didukung oleh suatu disiplin ilmu, bukan sekedar common sense, (4) ada kode etik yang menjadi pedoman perilaku anggotanya beserta sanksi yang jelas dan tegas terhadap pelanggar kode etik, dan (5) sebagai konsekwensi layanan yang diberikan kepada masyarakat maka anggota profesi memperoleh imbalan finansial atau meterial.

Tugas-tugas pendidik diantaranya: sebagai tenaga profesioanal, sebagai perencananaan, melaksanakan pembelajaran, menilai, membimbing, melatih, mengabdi pada masyarakat, meneliti.

Dan contoh profesi pendidik diantaranya: guru, dosen, instruktur, tutor. Pamong belajar, konselor, widyaiswara, fasilitator, dan penguji.

Daftar pustaka

Afriansyah, H. (2017). Administrasi Pendidik Dan Supervisi. Padang: Osf.Io. Https://doi.org/DOI 10.17605/OSF.10/6TX2W

Mariyana, R. (n.d.) ETIKA PROFESI GURU oleh : Rita Mariyana Supriadi, D.(1999). Mengangkat Citra dan Martabat Guru. Jakarta: rosda karya. UU. No. 20 tahun 2003 Tentang Sistem Pendidikan Nasional. (n.d.) 
